\title{
ETHNOGRAPHIC HERITAGE AS A TOURISTVALUE OF NATIONAL PARK DJERDAP
}

\author{
Dobrila Lukić, \\ Aleksandar Joksimović
}

Alfa BK Univerzitet

Correspondence:

Dobrila Lukić

e-mail:

dobriladjerdap@gmail.com

\begin{abstract}
:
Lately, cultural heritage has become increasingly recognized as themain forceof economic development within different regions and countries. The establishment of cultural heritage as a function of tourism promotes the development of various crafts, contributes to the employment of local population, enables the production of unique souvenirs, preparation of new gastronomic specialties, construction of hotels that are consistent with the surrounding environment, etc. Imaginative and creative use of cultural heritage is the main appealof cultural tourism in which the modern tourist represents an active participant in the events and requires immediate experience at a particular destination. Djerdap National Park, the oldest and largest national park in Serbia, has numerous elements of ethnographic heritage which can be primarily put into function of folklore tourism as a specific type of cultural tourism. In this regard, this paper provides an analysis of the customs, traditional food, beliefs, folk dance and national costumes of the residents of Djerdap as a complementary tourism value of this region.
\end{abstract}

Keywords:

Djerdap National Park, cultural tourism, folklore tourism, ethnographic heritage, tourist value

\section{INTRODUCTION}

The World Tourism Organization has given the definition of cultural tourism, according to which this type of tourism represents "any movement of people with the goal of satisfying human needs for diversity, aiming at raising the individual's cultural awareness and creating new knowledge and experiences" (UNWTO). The European Cultural Tourism Network (ECTN) defines cultural tourism as a "tourism based on local and regional cultural resources" (http:// www.culturaltourism-network.eu/award-2018.html). This indicates that the cultural tourism is based on culture, tradition, history, environmental entities, archeological sites, museums, but is also based on the activities such as festivals, theatres, activities related to the ways of earning, to the crafts and lifestyle of acertain region's population. Djerdap National Park has rich ethnograpic heritage that can serve as a basis for developing this type of tourism. It was proclaimed a National Park in 1974, and it covers the area of about 65000 ha of the territory of municipality Golubac, Majdanpek and Kladovo (Lukić, 
2005). Apart from the Serbs and the Vlachs who speak both the Serbian and Vlach language, and who declare themselves as Serbs, there are also settlers from Kosovo, from Lika, Užice region, Macedonia, as well as from Romania, Hungary, the Czech Republic and Bavaria (Barjaktarović, 1973; Cvijić, 2000). Such ethnic diversity of the population is the basis for the development of folklore tourism as a special type of cultural tourism in Djerdap. Tourists can visit various manifestations regarding folk art and crafts, where they can get acquainted with the bridal customs, customs related with harvesting, sowing, Easter, Christmas and other customs and rituals, as well as with the national dance, beliefs, traditional food and national costumes. In this way, the presentation and interpretation of the multiculturalism and interculturality of this area is performed (Hadžić et al., 2005).

\section{TRADITIONAL CUSTOMS AMONG THE RESIDENTS OF DJERDAP}

There are plenty of customs whichhold a significant place in the life of this region's residents. However, a great number of these customs has been lost due to the increasing influence of the modern lifestyle and this region's increasing accessibility to its close and far surroundings. The customs surrounding childbirth are relatively scarce, least preserved and most adapted to the modern way. The term Babine refers to the first forty days after childbirth. During this time, relatives and friends visit the woman who gave birth and bring her povojnica which includes the following items: pogača ${ }^{1}$ laced with honey, cakes, roasted meat, cheese, a canteen of wine or rakija ${ }^{2}$. If the infant does not get any povojnica, the people believe that the child will not be able to get married when it grows up. During the period of Babine, the woman is free of all work, although, there are exceptions, especially during the season of field work, when people don't follow these customs and the woman has to start working after just a few days of giving birth.On the first, the third or the seventh night after the birth of the child, according to the folk belief, fairies sudjenice ${ }^{3}$ gather around the newborn and determine its fate. It is advisable that the house be clean when sudjenice come. Also, the mother and child must wear clean clothes that night. Pogača, wine, basil and a coin are put next to the child, so that sudjenice help themselves after their tiresome trip. If the child is healthy, the day of baptism is being scheduled. The child is baptized after forty daysor after six weeks at the most, because it is considered that the devil has power over unbaptized children (Vlahović, 1974a). Death and traditional customs associated with it in the parts around Djerdap are very interesting toresearch. Among Vlach people in Djerdap, as in the other parts of East Serbia, there is still a strong belief in the cult of the dead. They still hold memorial services, pour outwater for the dead, they make priveg - a big fire resembling bonfire, around which they perform long ritual folk dance kolo, they perform special kolo for the dead, go to the cemeteries at night and they also burn ritual fires and until the end of the 20th century they also performed posthumous rituals of digging out the deceased and black wedding. All those magical and religious activities are followed by rich feasts, because it is considered that plenty of food, drinks and music helpthe deceased in the afterlife, which is a dark, cold and waterless place, to bring him into paradise and well-being (Vlahović, 1981; Antonijević, 1982). Krsna slava ${ }^{4}$ is a tradition originating from the ancient times, the pre-Christian, polygamous beliefs and customs. In those ancient times, every family or home community had its god protector to whom they prayed, into whom they believed, to whom they offered sacrifices, and from whom they expected help. With the appearance of Christianity, people found it hard to separate themselves from their patron saints, so the Christian preachers gradually assigned Christian features to numerous polygamous beliefs and customs. The necessary characteristics of the celebration of krsna slava are slavski kolač $\check{c}^{5}$ a candle, slavsko žito or $k o l j i v o^{6}$, frankincenseand wine. All additional things the host serves depend on him only and his finances. Slavski kolač represents an offering to please the god. Breaking the slavski kolač cross wisely represents the passion of Christ. After breaking slavski kolač they pour wine over it to symbolize washing off people's sins with the blood of Christ. Slavska sveća $a^{7}$ made of bees' wax represents a pure and innocent offering for the salvation and purification of the host's soul. The candle brings a holiday

1 Unleavened round sweet bread (translator's note)

2 A traditional Serbian alcohol drink made of fermented fruit, a type of brandy (translator's note)

3 Supernatural female beings originating from ancient Slavic religion that determine newborns' destiny. This deity is known to all Slavonic people under different names (translator's note)

4 Celebration of the family's patron saint's day (translator's note)

5 A special type of bread-like cake (translators note)

6 Consecated boiled and sweetened wheat with walnuts (translator's note)

7 A candle traditionally lit on slava(translator's note) 
light and solemnity into host's home. Slavsko žito - koljivo, panija-is served as an offering to the god as a sign of gratitude for all the earthly fruits and as a memory of the ancestors. It is a mistake to think that slavsko žito is prepared for the patron saint's peace of soul. Christmasis celebrated as a holiday that marks the memory of the day of birth of Jesus Christ, the son of God. Christmas is the most important Christian holiday and among the Serbs it is the holiday filled with the largest number of magical rituals and customs. Many of them originate from the ancient pre-Christian era - from polygamous times. All those customs aim at preserving and increasing the host's family and wealth. There are several holidays before and after Christmas that are interconnected by their church history and folk tradition and they are reffered to by a common name - Christmas holidays. These are: Detinjci, Materice, Očevi, Sveti Ignjat Bogonosac, Tudžindan, Badnji dan, Božić, Nekršteni dani, Mali Božić, Nova Godina, Sveti Vasilije, Krstovdan, Bogojavljenje i Sveti Jovan Krstitelj. Although Easter, after Christmas, represents the largest Orthodox holiday, it is not nearly as rich in customs as Christmas is. The Easter holidays include: Lazareva Subota (Vrbica), Cveti, Velika nedelja, of which the most important is Veliki petak (Good Friday), and finally Easter. In some regard, Spasovdan and Duhovi be included in Eastern holidays (Vlahović, 1974a).

\section{TRADITIONAL NUTRITION OF THE RESIDENTS OF DJERDAP}

Due to the fact that there is a small number of cultivable areas in the Djerdap region, cattle breeding and fishing are developed here, and also, to a smaller extent, agriculture on small alluvial plains. Therefore, the diet of the population consists primarily of fish, meat, milk, dairy products and porridge - mamaljuga. However, as a result of modern socio-economic processes, there is an increasing deviation from the traditional diet. The various types of breads intended for different occasions are especially interesting. One of the most famous breads among them is grindjej or slavski kolač. It is decorated with figures that symbolize fertility. The bread is divided into four parts where each part has one figure: a bunch of grapes, a bird, a barrel or a flower. In more recent times, people started making gibanica ${ }^{8}$ and cake in the Djerdap region. The cake didn't appear in its traditional form in Tekija until the postwar years, and in Sipa in 1962 (Vlahović, 1974b). Yoghurt (drzar) is made of milk, and it is curdled. Kajmak ${ }^{9}$ is poorly used in the residents of Djerdap's diet. It is made by Montenegrin women from village Petrovo. Serbian white cheese brnza is the most famous one. However, Vlach's cheese is also fairly often used in nutrition and the way of making it is the same as with the Serbian cheese, apart from it being boiled and dried up in slices so it can last longer. Containers for storing milk and cheese are called galjate and oljej and are made of a single piece of linden tree. Today, these containers can rarely be seen. Milk and dairy products with mamaljuga are the main part of morning and evening meals for the cattle-breeding residents. Until the Second World War the cattle were bred for both domestic needs and for export, in this region. The meat was especially prepared for slava, daća $a^{10}$, holidays and for field work. Most often mutton was served, as a roast with potatoes and rice on the side. Meat was roasted under crepulja ${ }^{11}$. In the winter, pigs are slaughtered and from their meat people get lard and prepare dried meat. Today, when there are no more open hearthstones, the meat is dried in the curing sheds (Lukić, 2005). Meat is usually used for preparing more or less standard meals. Quite often livestock is also used as an offering in rituals in situations related to survival, progress and life. The fish here is prepared in different ways and the most valuable ones are: sturgeon, zander, beluga, starry sturgeon, catfish and carp. The fish is prepared for slava during fasting and for St. Nichola's Patron day, who is the protector of fishermen and sailors. In the villages around Djerdap, a famous gastronomic specialty isthe fish stewin which they put brine from sour cabbage instead of water and fish-roe which gives it a special flavor. Preservation of fish is done by salting, smoking and air-drying it. Kavijar-ajvar ${ }^{12}$ is prepared from fish-roe, using the technology brought by the Russian emigrants after the October revolution. The most delicious ajvar is made from the sterlet, because its fish-roe is large and black (Vlahović, 1974b; Lukić, 2005).

8 A traditional cheese and egg pie (translator's note)

9 A type of cream derived from milk (translator's note)

10 A meal people eat at funerals, so the deceased can rest in peace (translator's note)

11 A baking lid (translator's note)

12 Ajvar is a red pepper chutney and ajvar-kavijar is a mixture of ajvar and caviar (translator's note) 


\section{FOLK BELIEFS IN THE DJERDAP REGION}

People's folk beliefs in the Djerdap region represent a curiosity, since they are identical among both the Vlachs and the Serbs, on both sides of the Danube. They believe in mythical creatures and in myths originating in nature: animals, plants and natural phenomena. The last one was built on once asignificant base on which the existence of these people depended (Lukić, 2005). In this region there are many beliefs in mythical creatures. These beliefs have different origins and are entirely of pre-Christian character. The demons people believe in can be classified into the following categories: demons that originate from living people, demons ofnature, demons who have influence on people's fate and, finally, all other mythical creatures whose origin and character can hardly be clarified for now. In the last group we can include so called todorci, rusalke, etc. (Zečević, 1974). Talasoni represent good spirits that guard certain buildings and they originate from people whose shadow is embedded in the respective building. When such aman dies, it is believed that his soul remains permanently bound to that building as its protector. The origin of this belief has roots in the ancient times when there was a practice of sacrificing people for the safety of buildings. Later, the practice of walling people in was moderated by walling in their shadows, because people considered that a person's shadow was an integral part of their personality and even later there appeared the practice of sacrificing animals (Lukić, 2005). Beliefs in the after life and communicating between the two worlds are quite different from the Christian ones. In this region, beliefs in vampires have certain differences in comparison to other areas. The belief it self is quite old, as we can see from the Article No. 20 of Dušan's Code ${ }^{13}$, where it says that the ones who dig out and burn corpses to destroy them will be appropriately punished. Even in 1725 this phenomenon started being discussed across Europe and in 1732 the question of vampire existence was brought out before the Academy in Berlin. Then the term vampire, originating in Serbia, became a recognized term in the entire world (Zečević, 1974). According to this belief, a person who is dead and can't find peace in the grave becomes a vampire and comes back to this world in order to disturb the living. What is characteristic for this region is that people here believe in a living vampire. It is believed that vampire becomes of people who had been evil in their lifetime, people who have blue (evil) eyes, dead people whose graves have been disturbed or of decent peopleif an animal passes over or below the corpse while it's in the house. As for the afterlife, a person can become a vampire only in the period of 40 days after they're dead. After that period the soul definitely goes to another world. Since vampires disturb the living, they would start with people once closest to them and perform practical jokes and do other things that could endanger people's lives (a vampire can drain human's blood, torture them and kill them). As a preventive measure, in order to stop the dead from becoming vampires, various rituals are performed, both before the burial of the deceased and after the funeral. Some are so brutal that people sometimes desecrate and physically destroy the corpse. In this region, there is a belief that extremely evil people can become vampires while still alive, while on their deathbeds, struggling because death doesn't want to embrace them (Lukić, 2005). In Djerdap, as in all of the Eastern Serbia, people believe in extraordinary powers of an illegitimate child. This belief originates in pre-Christian religions. Achilles was the greatest Achaean hero in the Trojan War, and he was the son of an immortal goddess and a mortal man. In our folk beliefs, there are also multiple examples of relationships between humans and creatures such as dragons, fairies, etc, where out of these relationships children were born. Such a child is a half-god, it has great strength and is invincible, so even a part of such a being can protect other people from death. That is why there was a custom in Dobra village that when a soldier goes to war, he sews an illegitimate child's body particle into his waistband. The character and function of the water spirit in folk beliefs are precisely established, so its place can be easily determined in our as well asin general mythology (Zečević, 1974). Many parallels from other mythologies are also helpful. Because of them, this research has a firm foundation in making these basic conclusions. Wherever beliefs about the water spirit were preserved, the form of this mythical creature is the same everywhere. It is a dwarf in dimorphic form, in whom the human characteristics are prevalent. He lives in underwater castles of glass or crystal, where he takes his victims. Their half-animal form indicates that they have a totemic genetic component. The black color indicates the Htonian origin of this mythical creature. He is lustful and is a companion of the deities and demons in many mythologies. A striking characteristic of the water spirit is that he drowns people. However, sometimes he is the fishermen's assistant if they offer him sacrifices. However, in

13 A compilation of several legal systems that was enacted by Stefan Uroš IV Dušan of Serbia in 1349. It is considered an early constitution, or close to it; an advanced set of laws which regulated all aspects of life. (translator's note) 
the end, fishermen must suffer unnatural death. Drowning people could be interpreted as a human sacrifice to the spirit of water, which was widely known in pre-Christian religions. In this sense, beliefs in fishing successes can be interpreted, since the fisherman sacrificed himself for that (Zečevic, 1974). The Forest Mother is the forest mistress. People imagine her as a beautiful woman with black hair, long nails and big breasts, naked or dressed in white clothes. She may appear as an old and ugly woman with strong teeth. She is lustful and seduces young people. In addition to protecting the forest, her function is providing protection for pregnant women and newborns. But she also sends illnesses such as children's cryand insomnia. Classical parallels offer analogies with Artemis and Diana, and there is a strong Slovakian component in the formation of this mythical creature. The dragon is, according to the belief, half-man, half-animal, who changes his shape depending on the situation. It originates from the old carp, who, when it reaches a certain age, emerges from the Danube River and becomes a bird, while in contact with humans it becomes a man. The dragon is also lustful and has affairs with women. The dimorphic form, the ability of metamorphosis, the animal's origin and characteristics lead to the totemic origin of this demon (Zečević, 1974). Sudjenice are goddesses who determine people's fate when they're born. There are three of them. People imagine them as beautiful girls, who enter the house through the fireplace at midnight. Thetrial starts with the oldest one and end with the youngest whose word is final. This belief is common in Europe. Labor demons or midwifes are evil demons, who can cause trouble to the child or the mother within 40 days of childbirth. Similar demons appear in other Slavic nations. Apart from the personification of the čuma (a plague), other demons of diseases appear in the mythology of the Djerdap residents. They are known as milosnice, milostive or tetke (the aunts). They are a personification of measles, cholera and sore throat (Zečević, 1974). Among the group of Balkan's cattle-breeders Aromanians, there are mythical creatures known as rusalje who most often live near the springs around which they perform folk dance kolo. During the week of Pentecost, farmersare careful not to stand where these rusalje were dancing, so that they wouldn't go crazy. They come to women in their dreams, provoking trance conditions and also while they're producing handiwork during the week the rusalje come to visit. According to the belief, a farmer can beat them and triumph over rusalka by playing the flute (Antonijević, 1990). Enchanted by the flute, they fall into trance, reveal their secrets, tell prophecies and advise on how to triumph over evil. These mythical beings come into contact with people only during the week of rusalka or at Pentecost. The Vlachs imagine them as beautiful, young girls with their hair falling down their backs. They are dangerous in this period and can cause harm to people, especially to women. The most important belief is that these mysthical creatures can enter the human body as spirits, possess them and cause seizures during Pentecost and the words spoken during that trance come from rusalje (Đorđevic, 2018).

\section{FOLK DANCE AMONG THE DJERDAP RESIDENTS}

In the Djerdap communities, people mostly dance open $k$ olo ${ }^{14}$ where the roles of kolovodja ${ }^{15}$ and $k e c^{16}$ are the most important. The kolo dancers move to the right in a circle, swerving into concentric circles, so they often make up a mass of people which then slightly moves entirely uniformly. This dance is common at dance parties in closed spaces visited by the Vlachs. The Serbs prefer to dance in the open, where they can move more and tend to occupy as much space as possible. The rule is that the men start the dance, kolovodja and kec along with one more dancer, and then after all the men join, the girls and the women join them. The observers stand outside the kolo, and they join the dance from the outside circle as not to disturb the pair structure. The dancers can hold each other in various manners. The oldest type is considered to be holding the dancer next to you around the waist, the belt, or arms in arms. When they hold each other around the waist, their elbows are pressed against the body, which gives the impression of monolithic dance. When they hold their hands, the arms may be folded at the elbows and they wave following the music's beat. Men hold each other's shoulders and biceps, but such a posture is not traditional, it was created under the influence of dancers who came from other parts of the country (Mladenović, 1974). Although the open kolo is the main form of the Serbian folk dance, people can also dance closed kolo, which is not as traditional and other types of kolo are unknown. As for the magical-ritual dances dodolska dance was performed by a single female dancer and kraljička dance by

14 Traditional folk dance (translator's note)

15 The leader, the first dancer standing on the furthest right side

16 The last dancer in kolo 
a couple of girls. Special all-male or all-female kolo never existed, so the open mixed kolo is the main outer characteristic of dancing in the Djerdap region. Besides burial and marital rituals in the Djerdap region, there are not many preserved ritual games. Having no direct relation to the rusalje who are connected to the spiritual ritual of the Vlach residents, in Dobra village there is a preserved magical and ritual female game-kraljice (the Queens), in the Serbian community. Kraljice represents an initiation ritual (marking the passing into the marring years of girl's lives) and a ritual and magical game for fertility and welfare (Antonijević, 1990). Ceremonies related to weddings make up a special group, but they don't have characteristics of a ritual. They include the following: momino kolo, devojačko kolo, danc, kokonješće and šareno kolo, and all the other dances belong to a local repertoare of individual communities. Dances associated with death rites are less connected to the day of the funeral but are common during memorial services. For example, in Dobra village, when a young girl or a young man dies, they send them off in a manner similar to the weddings, people shoot and play music, but rarely dance. In Golubinje village, where the population is made up mostly of the Vlachs, people do not dance at the cemetery, but they play songs of grief, marches and kolo that the deceased loved (Mladenović, 1974). The Vlachs perform folk dances regularly during the time of pomana ${ }^{17}$, especially on the anniversary of death. They then perform Vlach folk dance with candles in their hands or dance kolo for the soul of the deceased holding his photograph in their hands. Most of the older folk dances are of Vlach origin and most of the modern ones are of Serbian origin. The main type of the dance is stara vlahinja or vlajnja, vlajna. This type of dance (choreographic pattern: 4 steps to the right, 1 to the left, 1 to the right, 2 to the left) includes: porečko kolo, truba, djerdapsko staro kolo, kalagoranjana, ora, majdanpek, gajde, etc. Due to its structure, this type of dance has the common name of četvorka (the foursome). This type of folk dance is not present in neighboring Romania, so it's considered to be autochthonous (Trifunović, 2018). Today's youth is not even familiar with some of these old dances: vlahinja, prepišor, Dajde Gica fa and tudorka. Among the old dances which are now known by name only, the most famous are: talambas, zvonce, sitan biser, andrijanka, trifunac. However, vlahinja is the most popular folk dance at celebrations and ceremonies, not so much because of the tradition, but because the dancers are outstanding, temperamental, drunk with its music, tireless in dancing and sensitive in terms of harmony. Folk dances in the Djerdap region are accompanied by instruments called karaba that can nowadays only be found in some old village on Miroč Mountain, or at salaši $i^{18}$ from where the so-called karabaši $^{19}$, the musicians, went to the villages. They also use instruments svirala (the flute) and $d u d u k^{20}$ for the dance music. The dancers cannot sing, because the dancing is long, temperamental and very exhausting (Janković, Janković, 1952).

\section{TRADITIONAL COSTUMES IN THE DJERDAP REGION}

Traditional costumes in this area are closely related to the costumes in the wider area of northeastern Serbia and with traditional costumes of people on the Romanian side of the Danube River. Serbian civic wear of the 19th century, which was popular until the First World War in the small towns of Golubac, Donji Milanovac and Tekija, was worn by older women. In the same time period, younger women and girls wore clothes in the European fashion. The rural immigrant population kept some elements of folk wear such as embroidered shirts and woven woolen aprons (Aranđelović-Lazić J, 1974). During the nineteenth century in Djerdap villages people wore an archaic cattle-breeder's ungureanVlach costumes. These costumes were worn by the people who lived in the areas from the Danube River to Paraćin, Rtanj and Zaječar and from the Morava to Porec River and the Timok. The same costumes were worn in Romania from the Danube to the Carpathians. The main parts of these costumes for men are hemp linen shirts and čakšire ${ }^{21}$ made of white cloth with straight legs and women wear long hemp shirts with plenty of ruffles around the neck and two special small aprons with long fringes. The top parts of these costumes, the same in women's and men's costumes, are gunjevi ${ }^{22}$ with sleeves - ajnaor

17 Commemoration of the deceased (translator's note)

18 A traditional type of farm in the Pannonian Plain region, typically remote from a town or village and consists of a family house, agricultural objects such as barn, stable and granary, surrounded by arable land and pastures. (translator's note)

19 Musicians playing karaba instrument (translator's note)

20 A type of flute (translator's note)

21 Traditional pants of Serbian national wear (translator's note)

22 Short homespun peasant coats (translator's note) 
šuba, or $z u b u n^{23}$ with short sleeves or without sleeves. These costumes are decorated with black or blue woolen cords sewn along the edges. There are two types of aprons in female traditional costumes. The back apron kecelja, šjukur, odnata, etc. has a slightly larger woven part with big ornaments and long fringes. It was worn with the front apron with no fringes, decorated with geometric ornaments or just stripes. The so-called konda made of linden bark in a shape of a circle and coated with a certain fabric is placed on the head. A white scarf is folded over this cap and a certain branch is put at the bottom corner. Around the hoop of kondja people put a corderoy band embroided with sterling and decorated with gold or silver coins. As the oldest part of the costumes in general, both for the Vlachs and the Serbsfrom the Morava to Kladovo, the shirt belongs to the so-called Carpathian or Pannonian shirt type with little ruffles around the neck. During the winter they wear $k o z ̌ u h^{24}$ (a sheepskin coat) or gunjevi. On their foot they wear opanak ${ }^{25}$ and socks made of cloth- kalconj. The most popular hat was a cone-shaped fur hat kašula, but Ungurean people wore round fur hats with long white hairs (Aranđelović-Lazić J, 1974, Lukić, 2005). Since the beginning of the twentieth century to the present day we can see that the national costumes of Vlachs Carana weren't very different fromthe old Ungureans's costumes, with some slight changes in attire of the village population. A Romanian scientist, Florea Bobu Florescu, has proven that the type of costume that is characterized by aprons with fringes originates from traditional clothes of pre-Illyrian or Illyrian-Thracian tribes. This Ungurean national wear is one of the most archaic on the entire Balkan Peninsula (Arendjelovic-Lazic J, 1974).

\section{CONCLUSION}

Different forms of cultural tourism are increasingly attracting tourists aged between 35 and 55 years, people who are, being fully economically and physically capable, ready to pay for their pleasure more than a passive tourist who belongs to mass tourism and only travels in order to swim or ski (Anderson, 2011). Since there are no objects of cultural heritage that could be classified into a category of independent tourism values in the Djerdap region, it is necessary to attract tourists in another way, that is, all the elements of natural heritage, as well as the elements of material and immaterial and cultural heritage of Djerdap should be integrated into a unique tourist offer and presented to the European and world tourism market. In that sense, the folk beliefs, customs, traditional nutrition, costumes and folk dances of the residents of Djerdap would complement the already existing tourism offer of Djerdap. Only in this way, this destination can become interesting enough to attract more visitors and contribute to the increase of both local and regional economic development of this part of Serbia. In this way local knowledge, tradition, cultural events, celebrations can be put into the function of tourism. This, of course, contributes to the increase in the sale of books, tourist guides, souvenirs, domestic products and services based on unique values of cultural heritage. Cultural tourism thus based ontributes to forming connections at different levels, namely between tour operators, caterers, carriers, i.e. connecting the public and private sector, as well as networking at local and regional level. In the future, a better presentation and interpretation of the ethnographic heritage of Djerdap is necessary in order to use folklore cultural resources to the furthest extent. For this reason, it is necessary to increase the inventiveness and creativity of the employees of the tourism industry in order to preserve the originality of the ethnographic tourism values of Djerdap, which has not been the case so far.

23 A type of a long vest (translator's note)

24 A sheepskin coat (translator's note)

25 A traditional leather footwear (translator's note) 


\section{REFERENCES}

Anderson, B. (2011). Cultural \& Heritage Travelers.VP American Express Business Insights.

Antonijević, D. (1982). Obredi i običaji Balkanskih stočara. Beograd: Balkanološki institut, SANU.

Antonijević, D. (1990). Ritualni trans. Beograd: Balkanološki institut, SANU.

Aranđelović-Lazić, J. (1974). Narodna nošnja u Đerdapu. Zbornik radova etnografskog instituta 7, 25-44.

Barjaktarović, M. (1973). O stanovništvu đerdapskih naselja. Zbornik radova etnografskog instituta 6, 23-38.

Cultural Tourism Network. (2018). Cultural Tourism - a Lever for Sustainable Development. Retrieved July15, 2018, from http://www.culturaltourism-network.eu/award-2018.html

Cvijić, J. (2000). Balkansko poluostrvo. Beograd: Srpska akademija nauka i umetnosti, Zavod za udžbenike i nastavna sredstva.

Đorđević, D. (2018). Rusalje - predanje iz sela Duboka. Kučevo: Centar za kulturu „Veljko Dugošević“.

Hadžić, O, Stojaković, G, Herman Milinković, K, Vanić, T., \& Ivanović, I. (2005). Kulturni turizam. Novi Sad: Departman za geografiju, turizam i hotelijerstvo, Prirodno-matematički fakultet.

Janković, Lj, \& Janković, D. (1952). Narodne igre. Beograd: Izdavačko preduzeće Srbije.

Lukić, D. (2005). Đerdapska klisura. Beograd: Srpako geografsko društvo.

Mladenović, O. (1974). Narodne igre đerdapskog stanovništva. Zbornik radova etnografskog instituta 7, 91-108.

Trifunović, D. (2018). Narodne igre Zvižda i Homolja. Kučevo: Centar za kulturu „Veljko Dugošević“.

UNWTO. (2015). Global Report on Cultural Routes and Itineraries. Retrieved July15, 2018, from http://cf.cdn. unwto.org/sites/all/files/pdf/global_report_cultural_routes_itineraries_v13.compressed_0.pdf

Vlahović, B. (1974a). Običaji stanovništva u naseljima đerdapskog područja. Zbornik radova etnografskog instituta 7, 57-78.

Vlahović, B. (1974b). Tradicionalna ishrana đerdapskog stanovništva. Zbornik radova etnografskog instituta 7 , 11-24.

Vlahović, B. (1981). Običaj „puštanje vode“ za pokojnike u Homolju. Zbornik radova etnografskog instituta 13, 65-75.

Zečević, S. (1974). Narodna verovanja đerdapskog življa - Verovanja u mitska bića. Zbornik radova etnografskog instituta 7, 79-90. 